\title{
A Fortunato Herrera, Ramón Ferreyra y César Vargas, por su labor botánica e interés en la conservación de la flora peruana
}

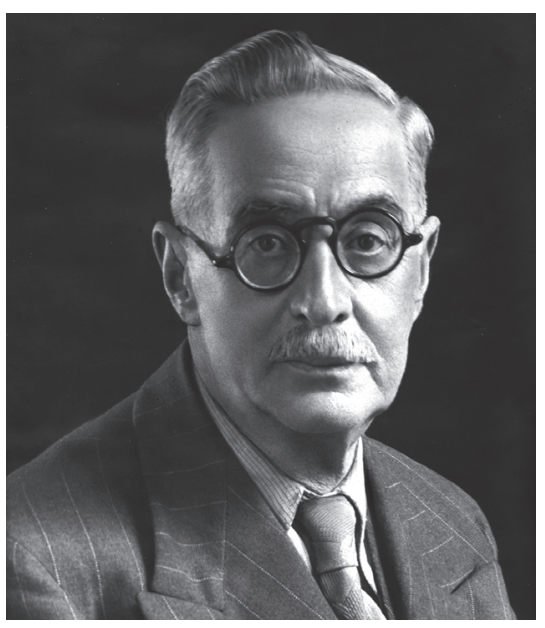

Fortunato Herrera

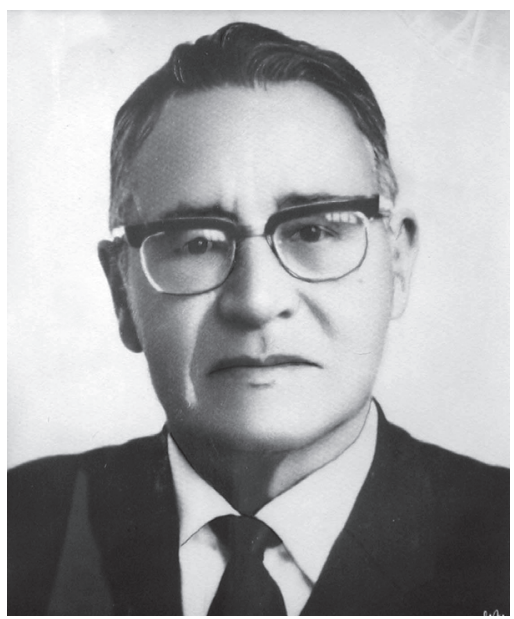

César Vargas

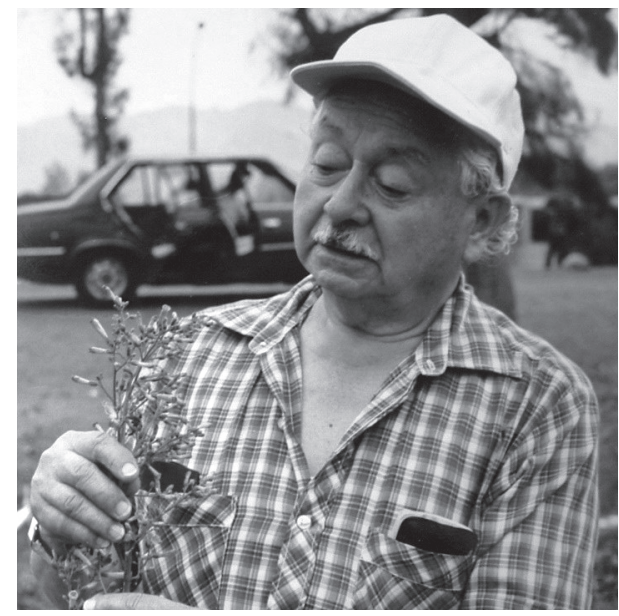

Ramón Ferreyra

Este volumen está dedicado a tres botánicos peruanos cuya pasión por registrar, describir y proteger la flora peruana marcó en el siglo XX el surgimiento formal de la disciplina botánica en el Perú. Gracias a ellos esta disciplina creció con el registro y compilación de la flora, así como se reforzó en el campo académico mediante la formación de varias generaciones de botánicos peruanos. A Fortunato Herrera debemos su visión por compilar los datos sobre la flora peruana; a Ramón Ferreyra y César Vargas debemos sus empeños por explorar el territorio nacional y documentar su flora. Sus colecciones botánicas permitieron el nacimiento de los herbarios peruanos como instituciones, insumos importantes para poder evaluar la riqueza de la flora, sus patrones de distribución y su estado de conservación.

(Fotos: César Vargas, cortesía de Norma Salinas; Ramón Ferreyra, cortesía de María A. Ferreyra Cerrate; Fortunato Herrera, cortesía del Sr. Adriazola, del Club Departamental Cusco) 